JACEK RUDEWICZ

Uniwersytet Szczeciński, Polska - University of Szczecin, Poland

\title{
Fab Laby w Polsce i na świecie jako przykład stymulowania przedsiębiorczości społecznej i kreatywności
}

\section{Fab Labs in Poland and in the World as an Example of Stimulating Social Entrepreneurship and Creativity}

\begin{abstract}
Streszczenie: Pod nazwą Fab Lab kryją się pracownie lub laboratoria oferujące dostęp do przestrzeni, narzędzi, urządzeń oraz materiałów osobom chcącym realizować własne pomysły, zaspakajać potrzeby i rozwijać pasje. Mieszkańcy miast mają często utrudniony dostęp do narzędzi i maszyn, a nawet miejsca. Dzięki specjalnemu wyposażeniu Fab Labów mogą tworzyć i naprawiać przedmioty, urządzenia lub doskonalić umiejętności twórcze bez uciążliwości i wysokich kosztów. Typowe Fab Laby wyposażone są w narzędzia stolarskie, elektryczne, często w drukarki 3D, elektronikę i komputery. W miejscach tych prowadzone są warsztaty przez osoby do tego przygotowane, co najważniejsze - korzystający z tych miejsc dzielą się ze sobą wiedzą i służą sobie pomocą. Fab Laby to nie tylko miejsca, ale też stowarzyszenia majsterkowiczów, modelarzy, architektów, artystów, inżynierów. Artykuł niniejszy powstał w celu przybliżenia idei tych miejsc, które zostanie dokonane przez ukazanie genezy tej aktywności przedsiębiorczości społecznej, inwentaryzację istniejących w Polsce przedsięwzięć tego typu, skatalogowanie ich możliwości oraz wyposażenia. Scharakteryzowana zostanie specyfika tej działalności, model biznesowy, oraz podjęta zostanie próba refleksji dotycząca rodzaju i stopnia wypełnienia przez te inicjatywy potrzeb lokalnych społeczności.
\end{abstract}

\begin{abstract}
Fab Labs are various types of laboratories or special spaces that offer access to space, tools, devices and materials for people who want to pursue their ideas, needs and passions. A lot of city residents often have difficult access to tools and machines, and even places. Thanks to the Fab Labs equipment, they can create, repair objects, devices or improve creative skills without the inconvenience and high costs. A typical Fab Lab is equipped with carpentry tools, electric tools, 3D printers, plotters, CNC milling machines, electronics and computers. In these places, classes and workshops are conducted by staff prepared for that. The very important function of these places is sharing knowledge, experiences and common help. Fab Lab is not only a place but an association of DIY enthusiasts, modellers, architects, artists, students and engineers. This article was created in order to explain the idea of these places, it will be done by showing the origin of this activity of social entrepreneurship, by the inventory of existing Fab Lab projects in Poland, by cataloguing the possibilities and their equipment. The specifics of this article are described, as well as the business model is characterised. The article ends with a reflection about the type and degree of fulfilment of the needs of local communities by these initiatives.
\end{abstract}


Słowa kluczowe: Fab Lab; fablaby; miasto; kreatywność; przedsiębiorczość; społeczeństwo; technologia; wytwarzanie

Key words: city; creativity; entrepreneurship; Fab Lab; manufacturing; MakerSpace; society; technology

Otrzymano: 14 listopada 2018

Received: 14 November 2018

Zaakceptowano: 21 lutego 2019

Accepted: 21 February 2019

\section{Sugerowana cytacja/Suggested citation:}

Rudewicz, J. (2019). Fab Laby w Polsce i na świecie jako przykład stymulowania przedsiębiorczości społecznej i kreatywności. Przedsiębiorczość - Edukacja [Entrepreneurship - Education], 15(1), 173-190. doi: 10.24917/20833296.151.13

\section{Wstęp: zakres przedmiotowy poruszanej problematyki}

Niniejszy artykuł ma charakter deskryptywny, zawiera elementy własnych badań. Jego celem jest przybliżenie i wyjaśnienie szerokiemu gronu odbiorców idei oraz sposobu funkcjonowania miejsc określanych mianem Fab Labów. Ten cel poznawczy zostanie osiągnięty przez ukazanie genezy tej aktywności przedsiębiorczości społecznej, opis działalności fundacji Fab Lab oraz inwentaryzację istniejących w Polsce i na świecie przedsięwzięć tego typu. W artykule opisane zostały wyposażenie Fab Labów oraz możliwości tych placówek w zakresie projektowania i wytwarzania. Scharakteryzowano także specyfikę tej działalności i zarysowano jej model biznesowy. W zakończeniu podjęta została próba refleksji dotyczącej rodzaju i stopnia spełnienia przez te inicjatywy potrzeb lokalnych społeczności. Artykuł i zawarte w nim treści oparte zostały na przeglądzie dostępnej literatury oraz bazie danych pozyskanej z Fab Lab Foundation ${ }^{1}$. Ze względu na stosunkowo niewielką liczbę opracowań w Polsce ma on charakter sygnalny. Obecnie (2018) brakuje kompleksowych badań Fab Labów, szczególnie w obszarze ich oddziaływania i efektów, dostępna literatura w tym zakresie jest jeszcze skromna. Tekst usystematyzowano wg wskazanych wyżej założeń, w części początkowej zawarto podbudowę teoretyczną. Artykuł zakończony został podsumowaniem, w którym opisano zarysowującą się zdaniem autora szerszą problematykę badawczą. Zawarto w nim rozważania dotyczące poszukiwania wspólnej nazwy dla Fab Labów i podobnych inicjatyw.

\section{Geneza idei Fab Labów}

Artykuł warto zacząć od tezy i jednocześnie myśli przewodniej, dotyczącej idei powstawania Fab Labów oraz związanego z nim ruchu. Brzmi ona następująco „Podział cyfrowy świata oraz ograniczony dostęp do wiedzy i informacji zmniejsza się przez technologie informacyjne, ale ciągle jeszcze istnieje luka w dostępie do technologii wytwarzania”. Teza ta powstała w wyniku obserwacji działalności i kompilacji licznych wypowiedzi profesora N.A. Gershenfelda.

\footnotetext{
${ }^{1}$ http://www.fabfoundation.org/
} 
N.A. Gershenfeld jest amerykańskim profesorem i dyrektorem MIT Center for Bits and Atoms. Jego działania naukowe koncentrują się głównie na interdyscyplinarnych badaniach z zakresu fizyki i informatyki w takich dziedzinach, jak obliczenia kwantowe, nanotechnologia i wytwarzanie osobiste. Profesor jest osobą niezwykle kreatywną, badania zespołów, którymi kieruje, dotyczą niestandardowych układów logicznych opartych na nanotechnologii. N.A. Gershenfeld jest znanym popularyzatorem nauki w Stanach Zjednoczonych. Jest m.in. członkiem American Physical Society. Według portalu Scientific American $^{2}$, należy do grona 50 najważniejszych amerykańskich naukowców. Został wymieniony przez Muzeum Nauki i Przemysłu Chicago wśród 40 współczesnych tzw. Leonardos. Jego osoba zyskała popularność również za sprawą stworzenia Great Invention Kit w 2008 r., kreatywnego zestawu konstrukcyjnego, który użytkownicy mogą wykorzystać w celu tworzenia różnych przedmiotów. Sylwetka N.A. Gershenfelda pojawiła się na stronach poczytnych magazynów „The New York Times” i „The Economist”, magazyn „Prospect” ulokował profesora wśród 100 największych intelektualistów świata. Neil A. Gershenfeld jest autorem kilku książek, m.in. Fab: The Coming Revolution on Your Desktop-From Personal Computers to Personal Fabrication (Gershenfeld, 2005). Niewątpliwe za sprawą tej książki i ekspresyjnych wystąpień publicznych osoba profesora stała się twarzą Fab Labów, za sprawą jego pomysłu i dzięki jego liderowaniu toczy się wokół tych miejsc wzniosła narracja i motywująca energia, może nieco na wyrost, lecz skuteczna i inspirująca wielu ludzi na całym świecie. Pierwszy Fab Lab powstał w MIT (Massachusetts Institute of Technology) w ramach interdyscyplinarnego laboratorium CBA (Center for Bits and Atoms) w 2001 r. Projekt ten finansowany był przez amerykańską National Science Foundation. Celem pierwszego i kolejnych Fab Labów jest podążanie za rewolucją cyfrową, a w szczególności za produkcją z wykorzystaniem technik cyfrowych. Fab Laby mają m.in. charakter edukacyjny i popularyzatorski, za cel przyjmują podnoszenie świadomości produkcji cyfrowej i osobistej. Celem zakładania Fab Labów jest też zdemokratyzowanie całego procesu - łańcucha wytwarzania, począwszy od projektowania, technologii i techniki do finalnego produktu. Według N.A. Gershenfelda, Fab Laby podążają i rozwijają się wra z upowszechnieniem Internetu (wypowiedź podczas prezentacji TEDx). Podobnie jak w sieci typu 2.0 oparte są na mediach społecznościowych, demokratyzują narzędzia projektowania i szeroko rozumianego tworzenia. Pozwalają milionom użytkowników stać się „aktorami” zamiast „widzami” produkcji cyfrowej i osobistej.

\section{Istota Fab Labów i założenia przedsiębiorczości społecznej}

Fab Lab jest to ogólnodostępne i niekomercyjne miejsce wyposażone w narzędzia tradycyjne oraz sterowane cyfrowo niezbędne dla każdego aspektu procesu rozwoju technologii i innowacji oraz wytwarzania. Począwszy od projektowania, do testowania, naprawy, monitorowania, wytwarzania, tworzenia dokumentacji. Pod obcobrzmiącą nazwą Fab Lab (spotykana pisownia: fablab, FabLab, fablabs, FLs. W artykule zastosowano wersję Fab Lab - jak nazwa własna marki) kryją się różnego rodzaju pracownie oferujące dostęp do przestrzeni, narzędzi, urządzeń oraz materiałów osobom chcącym realizować swoje pomysły, spełniać swoje potrzeby i rozwijać pasje. Nazwa to akronim słów z języka ang. Fabrication Laboratory. Mieszkańcy miast, mieszkańcy krajów rozwijających się, a także

\footnotetext{
${ }^{2}$ https://www.scientificamerican.com/
} 
Fotografia 1. Fab Lab Amsterdam

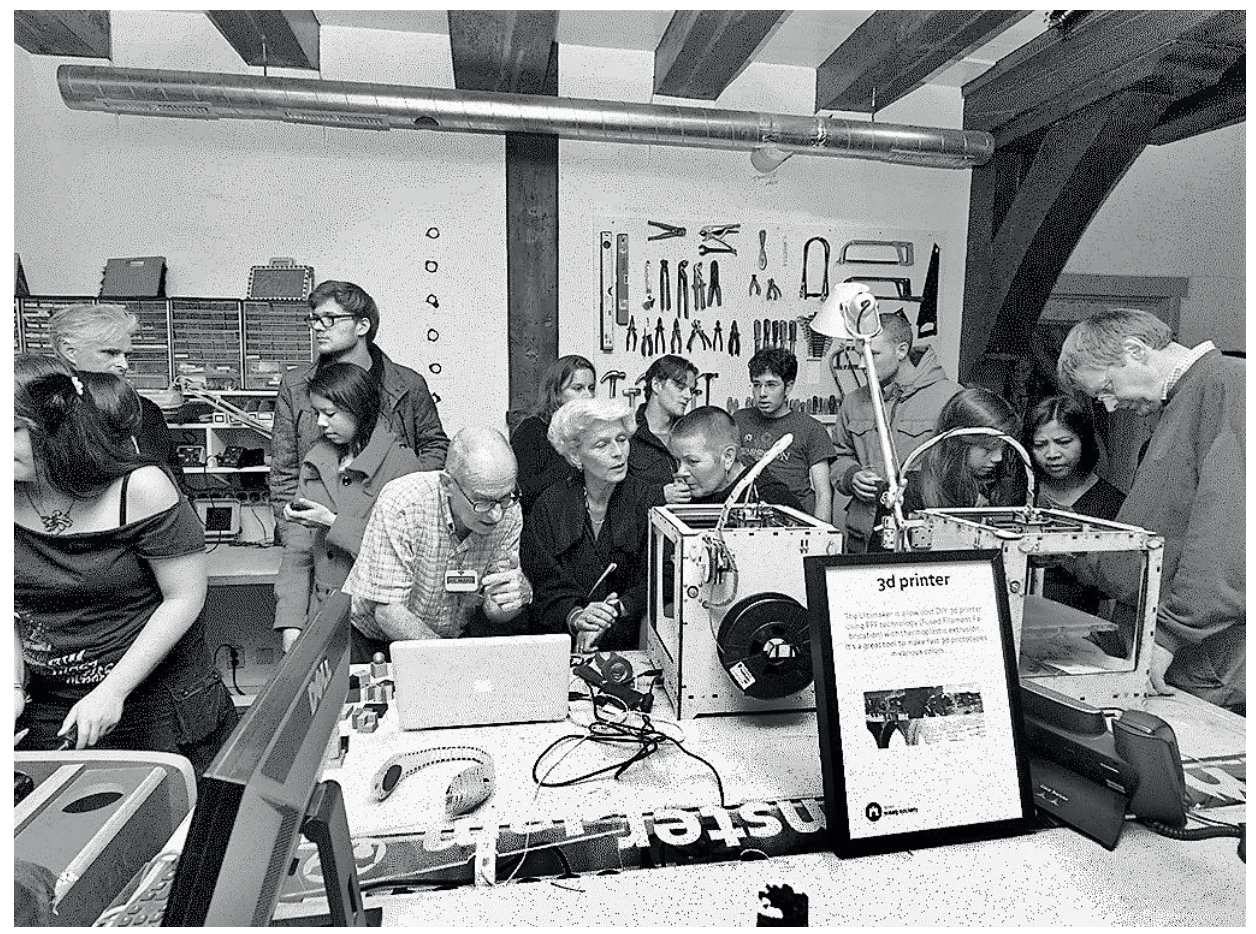

Źródło: Van der Moolen K. https://waag.org/en/article/how-set-fab-lab

rozwiniętych mają często utrudniony dostęp do narzędzi i maszyn, a nawet miejsca, nie posiadają środków finansowych i odpowiednich kompetencji. Dzięki wyposażeniu Fab Labów i pracującej w nich kadrze mogą jednak tworzyć, naprawiać przedmioty, urządzenia lub doskonalić umiejętności twórcze bez uciążliwości i wysokich kosztów. Typowy Fab Lab wyposażony jest w narzędzia stolarskie i elektryczne, drukarki 3D, sterowane komputerowo obrabiarki (CNC), elektronikę (np. platformy Arudino i mikrokomputery Rapsbery Pi) i komputery PC. W miejscach tych prowadzone są zajęcia i warsztaty przez przygotowane do tego osoby, a co najważniejsze - korzystający z Fab Labów dzielą się ze sobą wiedzą i służą sobie pomocą. Fab Laby to jednak nie tylko miejsce, ale też stowarzyszenia majsterkowiczów, modelarzy, architektów, artystów, inżynierów i studentów. Wyposażenie Fab Labów, o którym będzie mowa dalej, to narzędzia tradycyjne oraz cyfrowe do celów wytwarzania, w miejscach tych znajdują się także komputery i oprogramowanie do projektowania i designu.

Zaletą i specyfiką Fab Labów jest to, że dzięki internetowi tworzą globalną sieć, można też mówić o tym, że tworzą rodzaj międzynarodowego ruchu. Łączą się one w krajowe lub międzynarodowe asocjacje, np. Fab Lab Benelux, Rede of Fab Lab Brasil, Fab Lab Lat. Łączenie się w sieci dotyczy też konkretnych problemów lub grupy odbiorców, np. Fab Lab Kids, Green Fab Labs, Fab Lab City Global Initiative. Ideą tego ostatniego jest, aby miasta produkowały wszystko, co konsumują, co zgodne jest z wizją tzw. circular city i smart city.

Inicjatywa Fab Lab City została zainaugurowana w 2011 r. na konferencji „FAB7” zorganizowanej w Limie w 2011 r. przez Instytut Architektury Zaawansowanej Katalonii 
(Institut d'Arquitectura Avançada de Catalunya), Centrum Bit and Atoms MIT, Fundację Fab Lab i Radę Miasta Barcelony. Projekt jest zdecentralizowany i otwarty dla innych miast, jego celem jest stworzenie do 2054 r. miast samowystarczalnych i bardziej przyjaznych człowiekowi (więcej: https:/fab.city/). Według informacji ze strony Fab Lab Foundation istnieje ok. 20 większych asocjacji i grup Fab Labów. Największą z nich tworzy United States Fab Lab Network. Jej ideowe założenia można potraktować jako przykładowe, gdyż podobne zapisy statutowe i ideowe mają inne zrzeszenia Fab Labów. Według założeń programowych tego zrzeszenia jest to sieć ludzi, którzy dzielą się wiedzą, pomysłami i zasobami na poziomie lokalnym, krajowym i globalnym. Amerykańska Fab Lab Network, jak widnieje w jej opisie, to silna społeczność Fab Lab, która zwiększa udział w edukacji nauk ścisłych oraz technologii, tworzy nową generację przedsiębiorców, wynalazców i artystów. Aktywizuje i zmienia podejście do edukacji, sztuki i tworzenia. Jednoczy i kształci twórców, zmienia produkcję przemysłową w całym kraju, przyczynia się do odrodzenia amerykańskiej innowacji.

Rozważania nad Fab Labami oprzeć można na dwóch zjawiskach opisywanych w kontekście zjawisk powstających na styku współczesnej gospodarki i zmian społeczno-cywilizacyjnych. Są to odradzająca się przedsiębiorczość społeczna i koncepcja tzw. Industry 4.0. (Przemysł 4.0). Przedsiębiorczość społeczna definiowana przez portal ekonomia społeczna (http://www.ekonomiaspoleczna.pl/) jako „jeden ze sposób określenia działalności gospodarczej, która łączy w sobie cele społeczne i ekonomiczne. Bywa ona określana również jako gospodarka społeczna, a także ekonomia społeczna”. W Polsce nie ma przyjętej powszechnie definicji tego rodzaju przedsiębiorczości. Według projektu ustawy o przedsiębiorstwie społecznym (Ustawa o przedsiębiorstwie społecznym, 2015) przedsiębiorczość społeczna rozumiana jest jako: działalność łączącą w sobie świadome, samodzielne prowadzenie działalności gospodarczej z prowadzeniem działalności społecznej wyrażonej zarówno w dokumentach programowych oraz statutowych firmy, jak i w codziennym działaniu. Istotą przedsiębiorczości społecznej jest jej działanie w oparciu o lokalny solidaryzm, lokalne zakorzenienie i działanie na podstawie partnerstwa instytucji publicznych, prywatnych i społecznych. Definicję przedsiębiorczości społecznej można znaleźć również w raporcie Przedsiębiorstwa społeczne: czynniki trwałości raport z i fazy monitoringu przedsiębiorstw społecznych z 2011 r. (Kaźmierczak i in., 2011: 7-8) „przedsiębiorstwa społeczne to zespoły osób prowadzących niekomercyjną działalność gospodarczą mającą na celu reintegrację zawodową osób dewaloryzowanych na rynku pracy lub przynoszenie korzyści społecznościom w postaci poprawy jakości życia ich członków, w tym także stymulowania lokalnego rozwoju społeczno-ekonomicznego poprzez dostarczanie towarów i/lub usług użyteczności publicznej”. Inne definicje przytaczane m.in. przez J. Hausnera i N. Laurisza (Hausner, Lauriusz, 2008) za autorami brytyjskimi podkreślają działanie przedsiębiorstw społecznych na rzecz lokalnych wspólnot, wspólnotowy charakter zarządzania i brak zorientowania na dystrybucję kapitału.

Przedsiębiorczość społeczna ma charakter oddolny, powstaje naturalnie $\mathrm{w}$ nielicznych zbiorowościach i na rzecz tych zbiorowości działa, ma zatem konotacje lokalne. Ekonomia społeczna spełnia szereg funkcji. Po pierwsze, aktywizuje i włącza na rynek pracy, daje szanse osobom wykluczonym w różny sposób, czy to przez wiek, czy też upośledzenie i niepełnosprawność. Po drugie, edukuje i uczy nowych kompetencji, po trzecie, wytwarza nowe dobra i usługi społecznie użyteczne. Niesie zatem korzyści dla dwóch stron wymiany na rynku wytwórcy i konsumenta. 
Fab Laby a koncepcja produkcji przemysłowej 4.0

Kontrowersyjna koncepcja „Przemysł 4.0” jest stosowana w odniesieniu do kolejnej rewolucji przemysłowej - która ma miejsce obecnie ${ }^{3}$. Ta „rewolucja” przemysłowa została poprzedzona trzema innymi rewolucjami przemysłowymi w historii ludzkości. Pierwszą rewolucją przemysłową było wprowadzenie mechanicznych urządzeń produkcyjnych w drugiej połowie XVIII w. i rozprzestrzenianie się ich przez cały XIX w. Od lat 70. XIX w. pojawiająca się elektryfikacja i podział pracy (tj. Tayloryzm) doprowadziły do drugiej rewolucji przemysłowej. Trzecia rewolucja przemysłowa, zwana także „rewolucją cyfrową", powstała w latach 70. XX w., kiedy zaawansowana elektronika i technologie informacyjne spowodowały daleko idącą automatyzację produkcji. Termin „Przemysł 4.0” pojawił się w $2011 \mathrm{r}$., z inicjatywy „Industrie 4.0” - zapoczątkowanej przez niemieckie stowarzyszenia i przedstawicieli biznesu, polityki i świata nauki - która promowała ideę jako podejście do wzmacniania konkurencyjności niemieckiego przemysłu wytwórczego (Kagermann, Wahlster, Helbig, 2013). Niemieccy naukowcy opisują swoją wizję „Industrie 4.0” w następujący sposób: W przyszłości firmy będą tworzyć globalne sieci, sieci łączące maszyny, systemy magazynowe i urządzenia produkcyjne w kształcie systemów cyfrowo-fizycznych Cyber Physical Systems (CPS). W środowisku produkcyjnym te systemy cyberfizyczne obejmują inteligentne maszyny, systemy przechowywania i urządzenia produkcyjne zdolne do autonomicznej wymiany informacji, wyzwalania działań i kontrolowania siebie nawzajem. Powoduje to usprawnienie procesów przemysłowych związanych z produkcją, inżynierią, wykorzystaniem materiałów i łańcuchem dostaw oraz zarządzaniem cyklem życia produktu. Inteligentne fabryki, które już zaczynają się pojawiać, stosują zupełnie nowe podejście do produkcji. Inteligentne produkty są jednoznacznie identyfikowalne, mogą znajdować się cały czas i znać swoją historię, aktualny status i alternatywne drogi prowadzące do osiągnięcia docelowego stanu. Wbudowane systemy produkcyjne są wertykalnie połączone $\mathrm{z}$ procesami biznesowymi $\mathrm{w}$ fabrykach i przedsiębiorstwach i są połączone poziomo z rozproszonymi sieciami, którymi można zarządzać w czasie rzeczywistym - od momentu złożenia zamówienia.

Zaprezentowane wyżej założenia przedsiębiorczości społecznej i „Przemysłu 4.0” znajdują swoje odzwierciedlenie w idei Fab Labów, ale oczywiście skala tych przedsięwzięć i ich oddziaływanie jest tu mniejsza. W jaki sposób się to odbywa? Otóż u podłoża idei Fab Labów leży dążenie do demokratyzacji wytwarzania i upowszechnieniu technologii. Zgodnie z tezą postawioną na początku artykułu. Internet upowszechnił się przez ostatnie dwie dekady na świecie, dając wielu ludziom dostęp do sieci wymiany informacji, są oni zatem jej odbiorcami i twórcami, pobudza to także ich kreatywność. Wyposażenie Fab Labów to w większości urządzenia sterowane cyfrowo, na tyle uniwersalne, że dają możliwość kreacji i twórczego spełnienia. Znacznie większą barierą jest obecnie upowszechnienie technologii wytwarzania niż dostęp do informacji. Fab Laby mają być przyczółkami jej upowszechnienia, szczególnie w krajach, gdzie występują w tym zakresie braki. Można zatem twierdzić, że Fab Laby mogą przyczyniać się do obniżenia wykluczenia technologicznego, analogicznie do działań przeciwko wykluczeniu, które prowadzi przedsiębiorczość społeczna, choć w tym przypadku w zakresie pokonywania bariery dostępności i braku wiedzy na temat technologii, przez budowę mostu między informacją

\footnotetext{
${ }^{3}$ Inna nazwa - Industrial Internet (Bungart, 2014).
} 
a wytwarzaniem. Kolejną analogią między Fab Labami jest nastawienie na działanie oddolne, angażujące lokalne społeczności. Koncepcja Industry 4.0 w Fab Labach demonstruje się przez sposób ich funkcjonowania, gdzie zbiór pomysłów, dokumentacji przechowywany i udostępniany jest w „chmurze”, dzięki czemu nad danym projektem pracować może wiele zespołów i osób, a rezultaty pracy są zmaterializowane w całej sieci.

Fab Laby to inicjatywy zorientowane na użytkownika, wpływające na rozwój lokalnych społeczności, a te z kolei zorientowane są na zrównoważony rozwój i ekologię. Według autorów artykułu Impact of the FabLab Ecosystem in the Sustainable Value Creation Process (Osunyomi i in., 2016) Fab Laby tworzą „ekosystem” dla inicjacji przedsiębiorczości i innowacyjności (rycina 1). W ekosystemie tym ludzie - twórcy - i technologia wzajemnie się wzmacniają przez edukację, rozwiązywanie lokalnych problemów, tworzenie społecznie użytecznych inwencji. Poniżej zaprezentowano przykłady urządzeń wytworzonych w Fab Labach (fotografie 2 i 3).

Rycina 1. Oferta Fab Labów

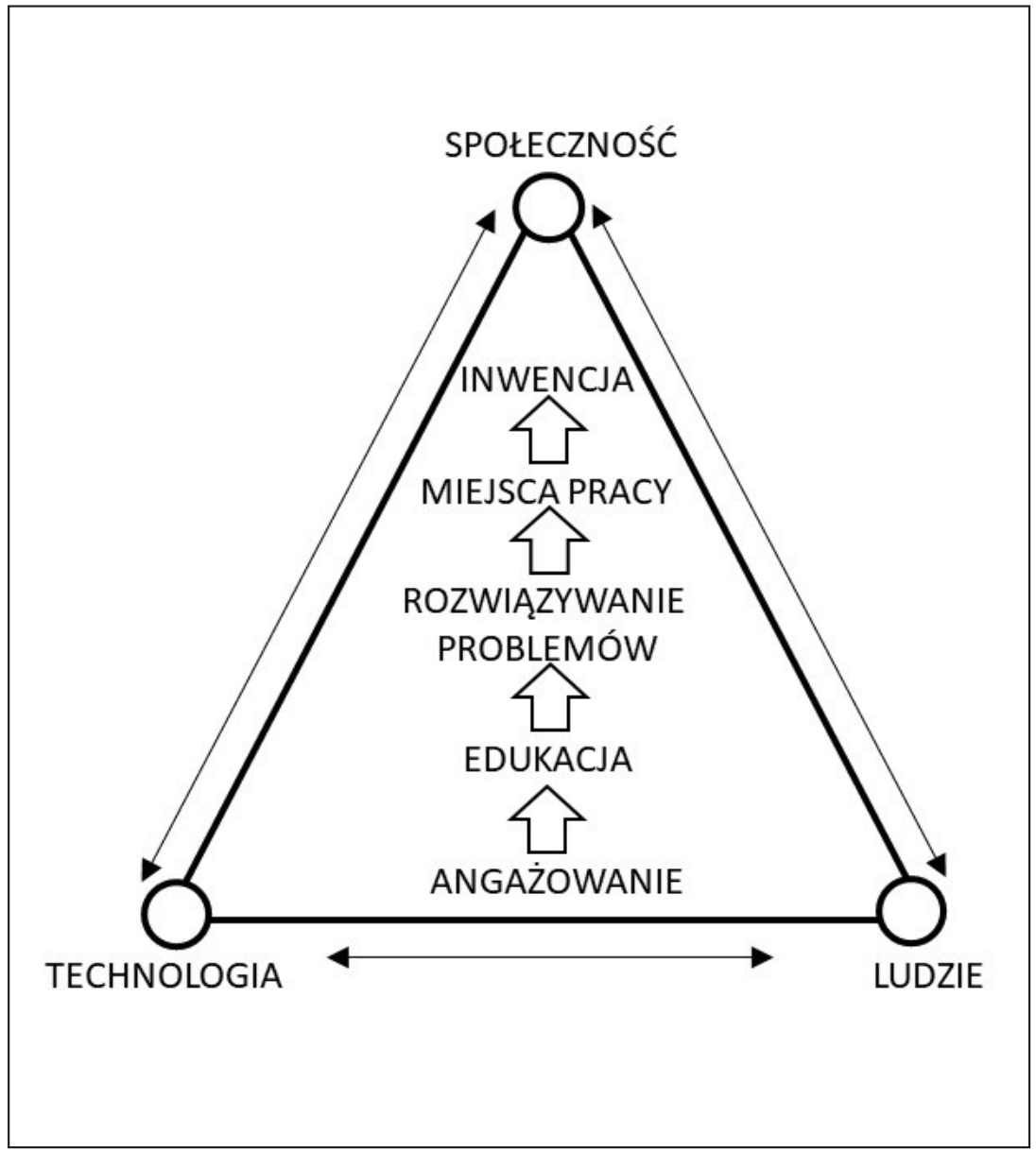

Źródło: Osunyomi (2016) 
Fotografia 2. Areocykl - Fab Lab Washington

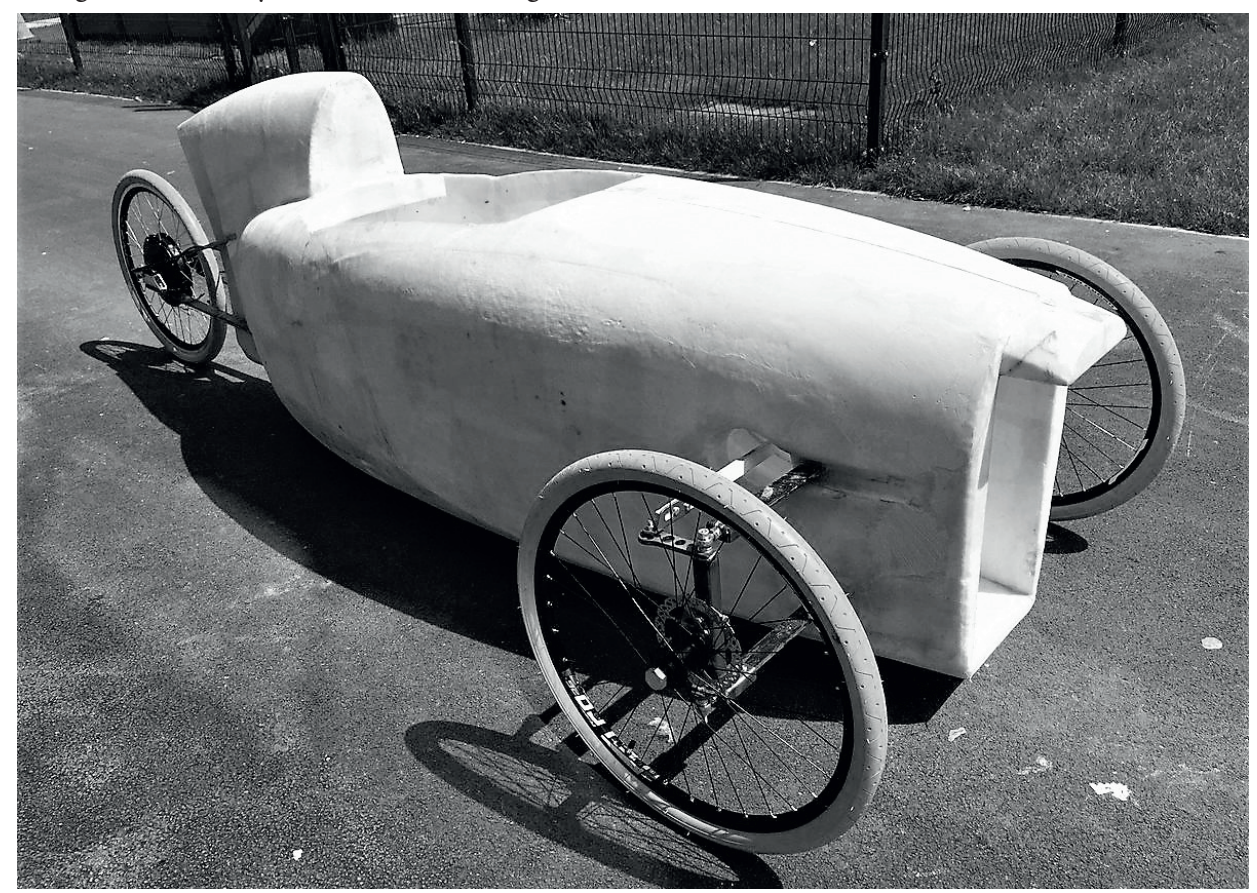

Źródło: https://twitter.com/FablabWarrBCA

Fotografia 3. „FabFi” anteny Wi-Fi zbudowane z siatki ogrodzeniowej i drewnianego szkieletu - Afganistan

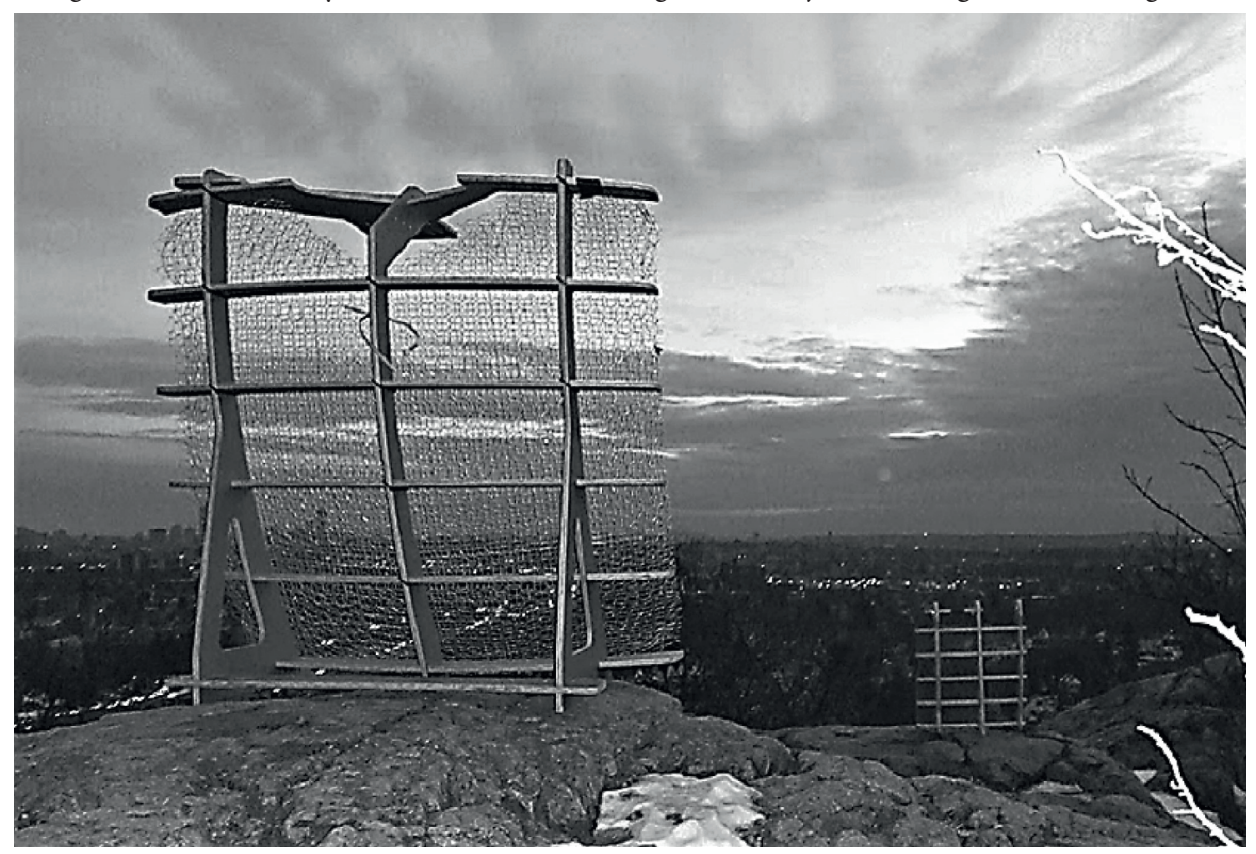

Źródło: Tokushima (2016) 


\section{Fab Laby w Polsce i na świecie: liczba i użytkownicy}

Łączna liczba zarejestrowanych w bazie danych Fab Lab Foundation miejsc tego typu na koniec września 2018 r. wyniosła 1314. Największą liczbą obiektów pochwalić się mogą Stany Zjednoczone, które mają ich 183 (rycina 2), kolejne państwa to Francja - 162 Faby Laby - oraz Włochy - 140 obiektów. Kolejne miejsca zajęły: Hiszpania, Brazylia i Indie nieco ponad 50 obiektów. Przy wielokrotnie mniejszej liczbie ludności państw europejskich nasycenie miejscami Fab Lab jest w ich przypadku znacznie intensywniejsze. Identyczną liczbą zarejestrowanych Fab Labów poszczycić mogą się Rosja i Holandia - 33. Stosunkowo niewielką liczbą w relacji do uprzemysłowienia państwa w liczbie tych miejsc wyróżniają się Niemcy - 49, Japonia - 18, Korea Pd. - 18, państwa skandynawskie. Wśród statystyk zaskakuje liczba (i jakość) Fab Labów w Gruzji (GE) - 25. W Kanadzie znajduje się 27 obiektów typu Fab Lab, podobnie jak w ludnych i ogromnych Chinach. Z obszaru Polski zgłoszono do ewidencji 13 placówek, daje to po zgłoszeniach z Rosji (33) drugie miejsce pod względem liczby zgłoszeń spośród państw Europy Wschodniej.

W odniesieniu do rozmieszczenia geograficznego Fab Labów na świecie (rycina 3) zauważyć można, że dominuje tu tzw. Północ, czyli Stany Zjednoczone i Kanada, oraz Europa Zachodnia, najmniej tego typu obiektów znajduje się na terenie Ameryki Środkowej oraz Afryki. Obecnie (2018) tego typu obiekty znajdują się na terenie łącznie 109 krajów.

Według badań D. Osunyomi, T. Redlich, S. Buxbaum-Conradi, M. Moritz, J.P. Wulfsberga (2016,) liczba Fab Labów w początkowym okresie rosła bardzo wolno. Prawdziwa eksplozja zapoczątkowana została w 2009 r. Wzrost w funkcji czasu przypomina krzywą logistyczną, gdzie po fazie embrionalnej nastąpił gwałtowny przyrost (rycina 4). Obecnie mamy 1316 Fab Labów, a ich liczba wzrasta.

W Polsce wg danych Fab Lab Foundation znajduje się 13 obiektów tego typu, natomiast wg nieautoryzowanych danych internetowych (Wikipedia) jest ich 19. Dane internetowe mogą być zawyżone ze względu na fakt, że niektóre inicjatywy oddolne i miejsca kreatywne przypominają Fab Laby, natomiast de facto nimi nie są i adekwatną nazwą byłaby dla nich np. Makerspace - miejsce twórcze. W tabeli 1 podano listę Fab Labów w Polsce. Widać z niej, że pod względem lokalizacji dominują duże miasta wojewódzkie (rycina 5), ale spotykane są wyjątki w postaci miast mniejszych - pkt. 6, 8, 13 i 14.

Tabela 1. Lista Fab Labów w Polsce w 2018 r.

\begin{tabular}{|l|l|l|}
\hline 1. FabLab Trójmiasto & 8. FabLab Sokołowsko & 15. FabLab Toruń \\
2. FabLab Łódź & 9. Fablab Szczecin Off Marina & 16. FabLab Kraków \\
3. FabLab Warszawa & 10. Fablab Rzeszów & 17. Fablab powered by Orange \\
4. FabLab Lublin & 11. Fablab Zielona Góra & Warszawa \\
5. FabLab Kielce & 12. Fablab Katowice & 18. Fablab Gdańsk \\
6. FabLab Niechanowo & 13. Fablab Wisła & 19. FabLab Bielsko-Biała \\
7. FabLab Poznań (Zakład & 14. FreeLAB Września & \\
\hline
\end{tabular}

Źródło: Wikipedia

Według szacunków pochodzących ze strony majsterkowo.pl, liczba Fab Labów w Polsce jest znacznie większa niż wykazano wyżej, wynosi ponad 50, z tym, że dodaje się do tego katalogu obok Fab Labów również obiekty tzw. Makerspace i pracownie programistyczne Hackerspace. Brak w Polsce aktualnej listy miejsc kreatywnych wynika z istniejącego jeszcze rozproszenia, dużej dynamiki ich powstawania i problemu zdefiniowania, czym one są. 
Rycina 2. Liczba obiektów Fab Lab na świecie (wrzesień 2018)

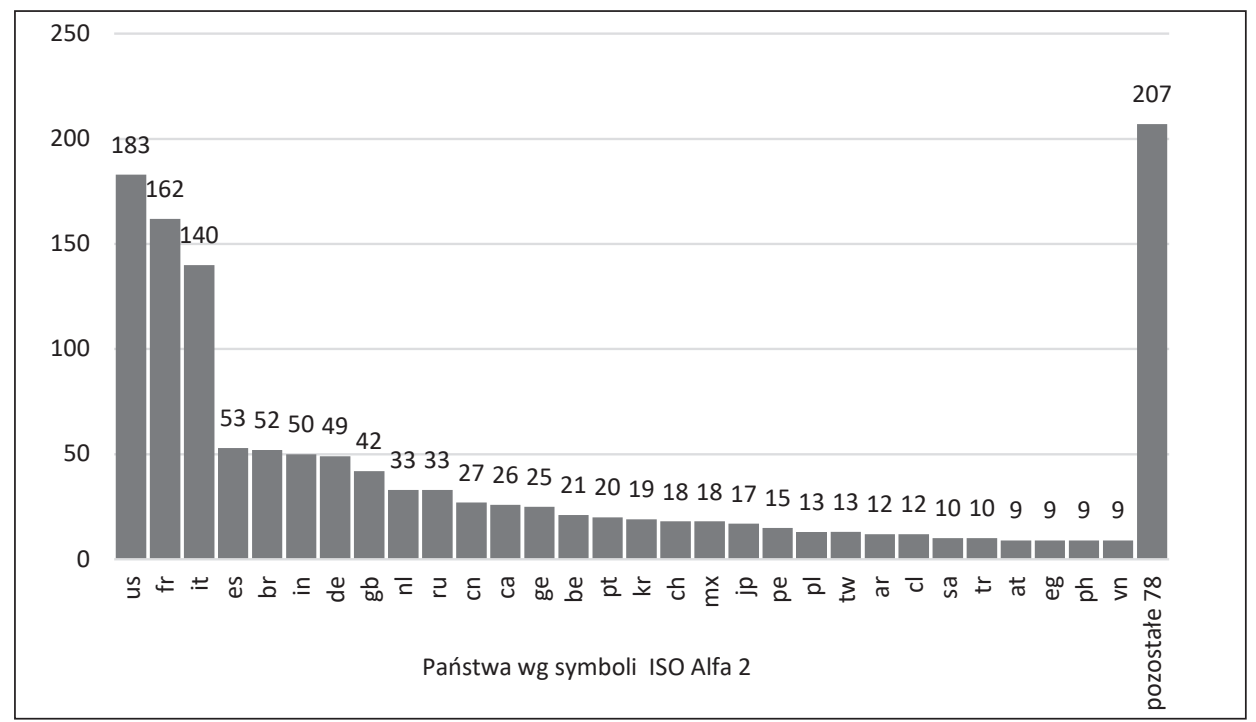

Źródło: opracowanie własne na podstawie bazy danych pozyskanej z Fab Lab Foundation

Rycina 3. Rozmieszczenie Fab Lab na świecie w 2018 r.

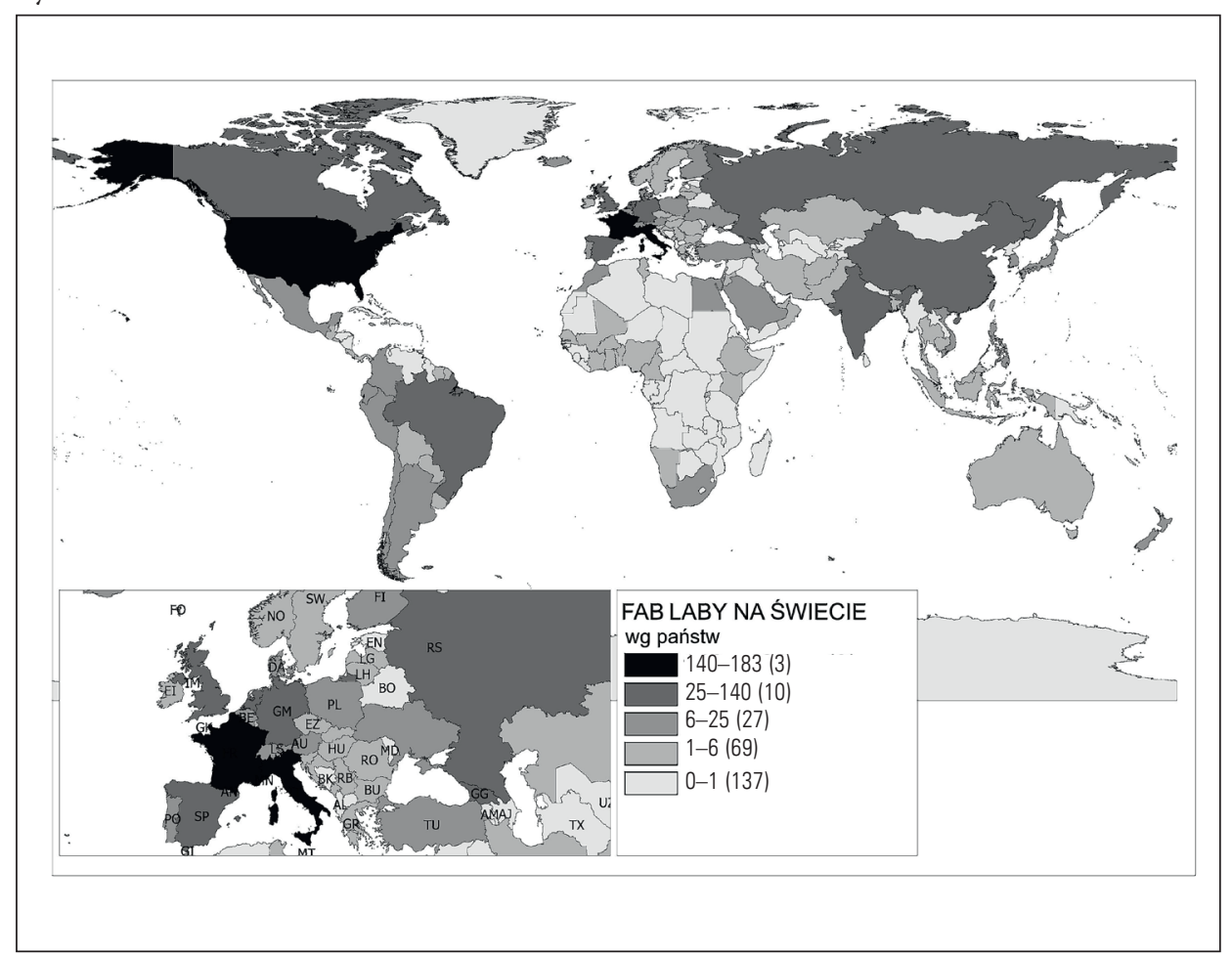

Źródło: opracowanie własne na podstawie bazy danych Fab Lab Fundation 
Rycina 4. Wzrost liczby Fab Labów w latach 2001-2015

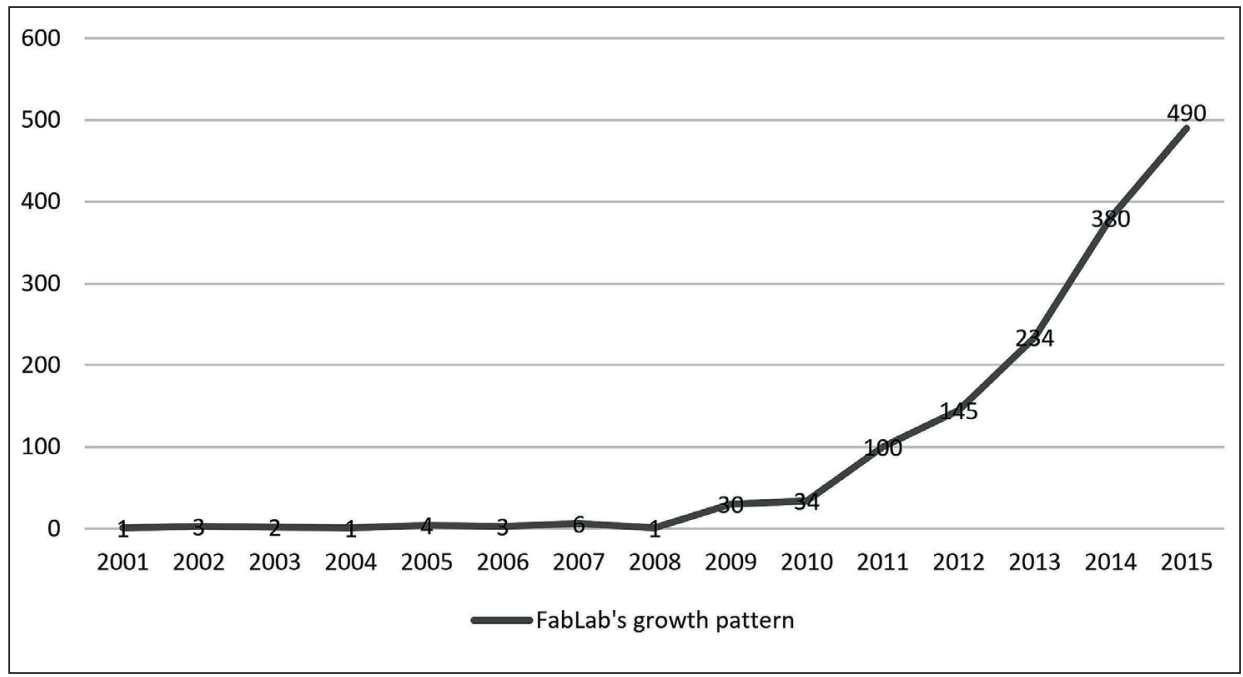

Źródło: Osunyomi i in. (2016)

Rycina 5. Fab Laby i inne miejsca kreacji oraz wytwórczości lokalnej w Polsce

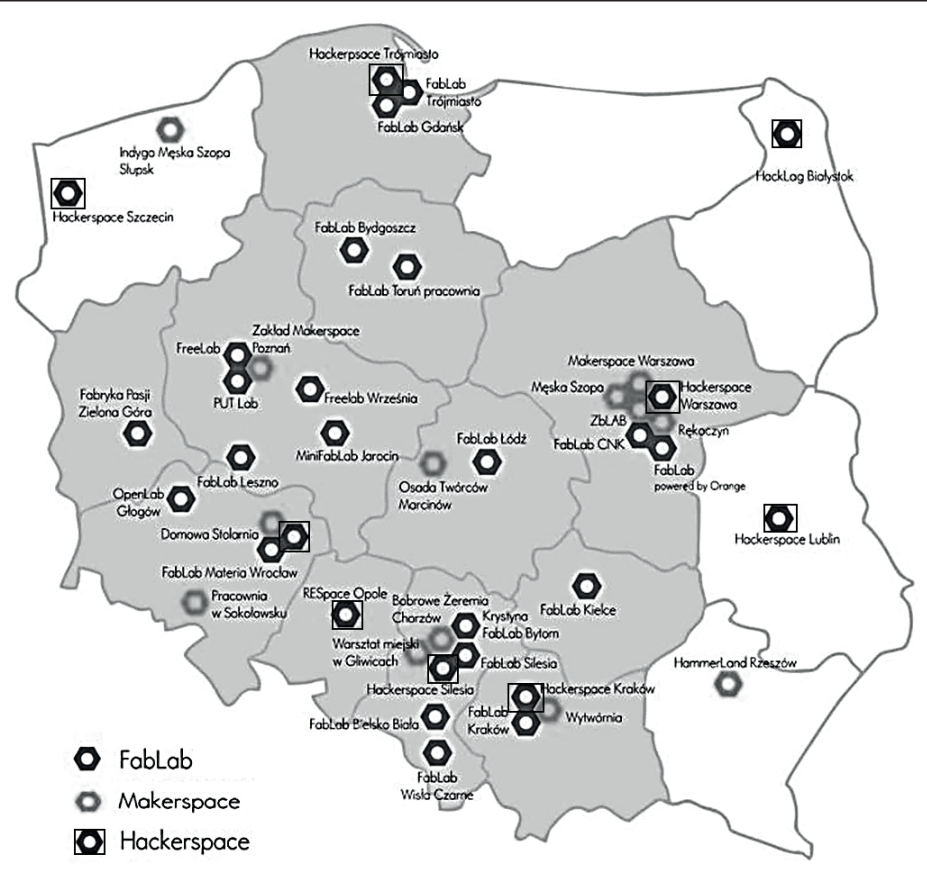

Źródło: L. Marczyńska Fab Lab Łódź za: www. majsterkowo.pl 
Fab Laby wg rozpoznania przeprowadzonego na podstawie bazy danych Fab Lab Foundation znajdują się w zdecydowanej większości w miastach. Wynika to naturalnie z potrzeb tego typu miejsc, którymi są przestrzenie, pomieszczenia oraz zaplecze, w szczególności kapitał ludzki i baza techniczna, którą znaleźć można w ośrodkach miejskich. Wiele spośród Fab Labów to przedłużenie działalności edukacyjnej, na poziomie wyższym skupionej w dużych ośrodkach miejskich. Pracownie/laboratoria tego typu powstają także przy uczelniach, technoparkach oraz, jak zauważono, w miejscach niegdyś spełniających komercyjne funkcje przemysłowe i produkcyjne. Patrząc na zagęszczenie wg poszczególnych miast, można stwierdzić, że najwięcej, bo aż 11 Fab Labów znajduje się w Tibilisi w Gruzji, 10 w Limie, 8 w Bostonie (tu powstawały pierwsze Fab Laby), Mediolanie i Paryżu, 7 w Istambule, 6 w Madrycie, São Paulo i Shenzen, w wielu miastach z Europy głównie stolicach regionów - istnieje do 5 obiektów Fab Lab.

Z miejskiego charakteru Fab Labów wypływa także kwestia profilu ich użytkowników. Według badań ankietowych (Osunyomi i in., 2016), w 94 wytypowanych placówkach tego typu w krajach rozwiniętych i rozwijających się stwierdzono, że największe grono stanowią (rycina 6) studenci - 69 wskazań (bezwzględna liczba wskazań w kwestionariuszu). Uczniowie zostali wskazani 16 razy, zwykli mieszkańcy (w tym osoby na emeryturze, członkowie społeczności, freelancerzy i turyści) - 41 razy, specjaliści (grupa ta obejmuje inżynierów oprogramowania, inżynierów, artystów, projektantów, nauczycieli, badaczy, twórców itp.) - 43 razy, członkowie różnych organizacji - 26 razy, użytkownicy różni (all/mixed) - 18 razy, organizacje pozarządowe (NGO) - 4 razy, przedsiębiorcy - 18 razy, bezrobotni - 3 razy, a na koniec jeden respondent wskazał organizację rządową.

Profil użytkowników determinuje też wiek osób korzystających z usług Fab Labów. W czasie badań (Osunyomi, 2015) 34 bezwzględnych wskazań to dzieci poniżej 12 roku życia, 55 przypadków to osoby z grupy wiekowej od 13 do 20 lat, 87 uczestników uznało frekwencję osób z grupy wiekowej od 21 do 35 lat, a 67 wskazało na obecność w grupie wiekowej powyżej 35 roku życia. Reasumując, przeważają osoby w wieku szkolnym, licealnym i studenckim. Kolejne pytania kwestionariuszowe wykazały, że 17 przedstawicieli Fab Labów stwierdziło, że ma 10 lub mniej odwiedzających tygodniowo, 32 wskazuje, że ma od 10 do 30 odwiedzających tygodniowo, 19 zaznaczyło, że ma od 30 do 50 odwiedzających tygodniowo, 15 - że mają od 50 do 100 odwiedzających w tygodniu, a 11 Fab Labów wykazało, że ma ponad 100 odwiedzających tygodniowo.

W celu dokładniejszego wyjaśnienia, jak działają Fab Laby i co są w stanie wytworzyć, zbadano na podstawie bazy danych (liczbie rekordów $n=1316$ ) ich główne wyposażenie narzędziowe. Według klasyfikacji bazy danych posiadają one 6 głównych typów urządzeń cyfrowo-produkcyjnych, jednak wyposażenie poszczególnych miejsc w te urządzenia jest zróżnicowane (rycina 7). Głównym i najczęściej spotykanym typem urządzeń są drukarki 3D (trójwymiarowe) - wyposażone jest w nie 91\% placówek. Drukarki 3D pozwalają wydrukować, a bardziej - stworzyć przedmiot, detal w rożnych technologiach z gotowego modelu trójwymiarowego w komputerze, materiałem, z którego tworzony jest przedmiot, są głównie tworzywa sztuczne, sproszkowany gips, metale lub specjalne żywice utwardzane światłem lasera lub UV. Kolejną grupą urządzeń, w które wyposażone są Fab Laby, są plotery laserowe (79\%). Pozwalają one na wycinanie i grawerowanie skomplikowanych wzorów na dużych, płaskich powierzchniach papieru, drewna (sklejki), metalu. Trzeci

\footnotetext{
${ }^{4}$ Badanie kwestionariuszowe z możliwością wielu wskazań w jednym pytaniu.
} 
Rycina 6. Typy użytkowników Fab Labów wg badań ankietowych

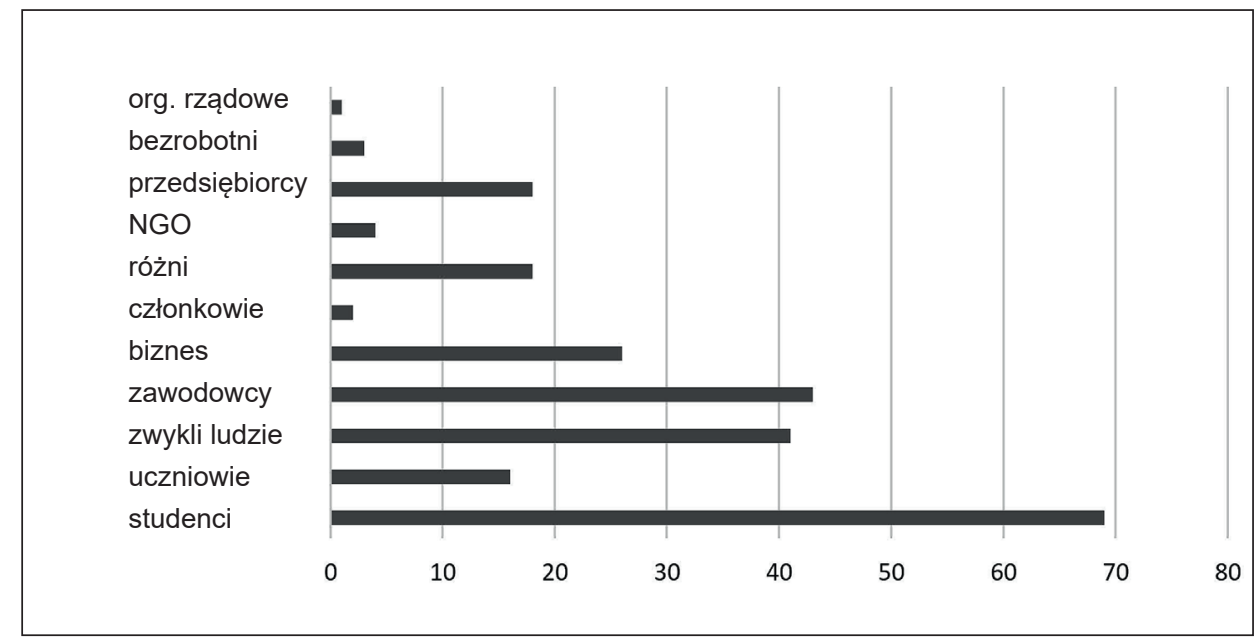

Źródło: Osunyomi (2015)

Rycina 7. Wyposażenie Fab Labów wg typów urządzeń $(\mathrm{n}=1316)$

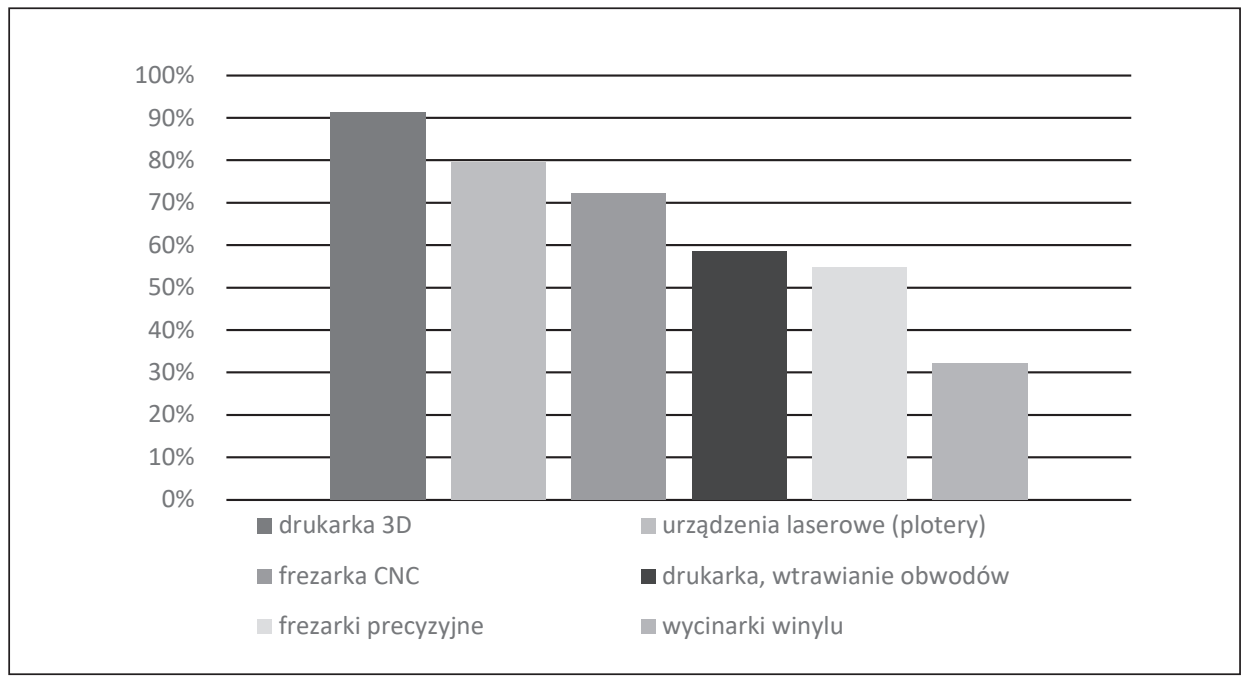

Źródło: opracowanie własne na podstawie bazy danych Fab Lab Foundation

zbiór maszyn stanowią frezarki CNC (Computerized Numerical Control) - wyposażone jest w nie 72\% Fab Labów. Obrabiarki te pozwalają tworzyć różne kształty w drewnie, metalu dzięki obróbce mechanicznej tzw. skrawaniem. W urządzenia do drukowania ścieżek i połączeń na płytkach krzemowych wyposażone jest 58\% Fab Labów. Urządzenia te pozwalają tworzyć elektronikę dzięki łączeniu w obwody układy scalone i podzespoły elektroniczne. Frezarki - obrabiarki precyzyjne to udział w wyposażeniu blisko 55\% obiektów. Są to urządzenia do detali, podobne do obrabiarek CNC, choć nie muszą być sterowane komputerowo. Najmniejszy udział w wyposażeniu Fab Labów mają wycinarki do winylu $-32 \%$. Działają one jak plotery, a wycinane w arkuszach winylu wzory służą 
jako szablony malarskie. Z powyższego zestawienia wynika, że 32\% wszystkich Fab Labów (w bazie danych) posiada pełen zestaw wymienionych urządzeń, ale nie wyczerpuje to całego instrumentarium tych pracowni. Spotyka się w ich wyposażeniu mniejsze urządzenia, np. oscyloskopy, mikrokomputery Rabsberry Pi, mierniki elektroniczne, maszyny do szycia oraz narzędzia popularne - manualne i elektryczne.

Typowy Fab Lab obok maszyn i narzędzi wyposażony jest w specjalne stoły robocze i stanowiska pracy. Według zaleceń Fab Lab Foundation, stanowiska pracy powinny być elastyczne i przenośne, użytkownicy powinni móc pracować osobno, ale także razem - grupowo. Pomieszczeniem, które jest bardzo ważne dla pracowni, jest tzw. open space, pomieszczenie do wspólnych spotkań i twórczych rozmów. Obok pomieszczeń dla uciążliwych urządzeń (hałas, pył) zaleca się wydzielenie pomieszczeń szkoleniowych oraz socjalnych i biurowych. Niezbędne jest zachowanie zasad BHP, co jest regulowane regulaminem. Najważniejszymi informacjami kierowanymi na zewnątrz dla pracowni tego typu są: grafik tygodniowej pracy, informacje o prowadzonych projektach i informacje organizacyjne publikowane na własnej stronie internetowej.

\section{Model biznesowy Fab Labów}

Fab Laby to miejsca, za usługi których co do zasady nie pobiera się opłat, ponieważ podstawą finansowania ich działania jest finansowanie zewnętrzne. Na podstawie danych ze stron internetowych Fab Labów oraz studiów literatury wyszczególniono podstawowe źródła finansowania - ze względu na wielość i jednoczesność tych źródeł finansowanie Fab Labów można określić mianem finansowania hybrydowego. Źródłami finansowania mogą być:

- fundacje - np. Narodowa Fundacja Nauki w USA, Fab Lab Foundation, organizacje pozarządowe,

- sponsoring (producenci narzędzi i oprogramowania),

- crowdfunding - np. środki poszukiwane przez platformę społecznościową Patronite,

- środki finansowe instytucji - uniwersytety, muzea, telekomy np. Orange,

- dotacje miejskie,

- opłaty i donacje, wynajem, wolontariat.

Użytkownikami pracowni są, jak już wspomniano, uczniowie i studenci, profesjonaliści, hobbiści i zwykli mieszkańcy. Kluczową rolę w działaniu tych miejsc odgrywa kadra lub inaczej - zespół Fab Lab. W strukturze organizacyjnej najważniejszą funkcję pełnią dyrektor i/lub Fab Lab Manager oraz trenerzy - instruktorzy poszczególnych sekcji. Obok nich w miejscach tych pracuje obsługa techniczna i organizacyjna oraz wolontariusze, o porządek dbają w dużej mierze sami użytkownicy. Poniżej wyszczególniono w punktach ogólną procedurę tworzenia Fab Labów. Procedura ta daje też wyobrażenie o sposobie funkcjonowania tych miejsc od strony organizacyjnej. Fab Lab Foundation Fundacja Fab Lab pełni w tym procesie funkcję koordynatora, wspiera wiedzą i doświadczeniem, wprowadza też pewne standardy (np. logotypy), podobnie do znanego z rynku komercyjnego franczyzowania, choć prowadzący tę fundację zaprzeczają. Oto poszczególne kroki podczas inicjowania działalności Fab Labów:

1. Wskazanie agencji hostingowej, przejęcie własności i odpowiedzialności za Fab Lab. Agencja hostingowa (gospodarz) może być dowolną organizacją, począwszy od NGO, agencji rządowej, organizacji społecznej, instytucji edukacyjnej itp. 
2. Wskazanie odpowiedniej osoby - mistrza (Fab Lab Managera), który poprowadzi Fab Lab.Fab Laby, które odnoszą sukcesy, są prowadzone przez właściwych mistrzów - liderów. Mistrz musi mieć wykazywać się pasją i zaangażowaniem dla rozwoju społeczności lokalnej przez technologię i powinien być osobą szanowaną przez społeczność lokalną.

3. Finalizacja umów partnerskich pomiędzy Fab Foundation / MIT a lokalnymi partnerami fundatorami i dostawcami usług.

4. Zabezpieczenie finansowania Fab Labu. Przez partnerów lub model PPP (Partnerstwa Publiczno Prywatnego), zespół Fab Foundation / MIT pomaga w budżetowaniu, pisaniu zapytań ofertowych itp.

5. Przygotowanie miejsca odpowiedniego dla działalności Fab Labu. Wybór miejsca ma kluczowe znaczenie - powinno być ono dostępne dla lokalnej społeczności i nie powinno zniechęcać potencjalnych użytkowników.

6. Procedura instalacji i uruchomienia Lab Fabu.

7. Szkolenie trenerów (techniczne i zarządcze). Właściwe szkolenia i przekazanie laboratorium zespołowi ma kluczowe znaczenie dla sukcesu Fab Labu. Najlepszy i najdroższy sprzęt bez odpowiedniej obsługi jest mało użyteczny.

8. Identyfikacja i wdrożenie projektów. Od samego początku pracownia może przystąpić do różnego rodzaju projektów regionalnych i globalnych lub prowadzić własne projekty.

9. Uruchomienie Fab Labu. Interesariuszy biorący udział w jego pracy dzieli się na społecznych, rządowych i prywatnych. Koszty wyposażenia Fab Labu mieszczą się w granicach 20-50 tys. dolarów, chociaż spotykane są miejsca wyposażone znacznie kosztowniej.

W tabeli 2 zaprezentowano przykładowy kosztorys wyposażenia.

Tabela 2. Przykładowy kosztorys podstawowego wyposażenia Fab Labu

\begin{tabular}{|l|l|c|c|}
\hline \multicolumn{1}{|c|}{ Narzędzia } & \multicolumn{1}{|c|}{ Zastosowanie } & Producent & $\begin{array}{c}\text { Koszt } \\
\text { [USD] }\end{array}$ \\
\hline Drukarka 3D i skaner & $\begin{array}{l}\text { tworzenie płytek PCB (do montażu } \\
\text { elektroniki) oraz urządzeń mechanicznych }\end{array}$ & ROLAND & 3800 \\
\hline Wycinarka do winylu & wycinanie precyzyjne wzorów & ROLAND & 2100 \\
\hline Oscyloskop & naprawa i budowa elektroniki & TEKTRONIX & 1300 \\
\hline Multimetr & pomiary i testowanie elektroniki & WAVETEK & 125 \\
\hline Generator funkcyjny & pomiary i testowanie elektroniki & B\&K Precision & 250 \\
\hline $\begin{array}{l}\text { Analizator widma } \\
\text { spektrum radiowego }\end{array}$ & pomiary i testowanie elektroniki & MIT & 1250 \\
\hline $\begin{array}{l}\text { UV-VIS spektrometr } \\
\text { (światła UV } \\
\text { i widzialnego) }\end{array}$ & charakterystyka materiałów & MIT & 200 \\
\hline Tower Kit 1 & szerokie zastosowanie & MIT & 1000 \\
\hline Mikronarzędzia & rożne & Inni & 1500 \\
\hline PC & komputer & IBM & 1500 \\
\hline Mikroskop & obserwacja i prace precyzyjne & INTEL & 50 \\
\hline Kamera cyfrowa & dokumentowanie i transmisje na żywo & CANON & 300 \\
\hline Skaner & dokumentacja & HP & 125 \\
\hline Razem & & & 13500 \\
\hline
\end{tabular}

Źródło: opracowanie własne na podstawie Mikhak i in. (2002) 
Obserwując sposób finansowania i tworzenia Fab Labów, można wywnioskować, że każdy z nich stanowi odrębny przykład finansowania i co do zasady nie jest pomysłem na zarabianie pieniędzy. Jednak według uogólniających badań przeprowadzonych przez badaczy (Osunyomi i in., 2015), Fab Laby pobierają drobne opłaty za członkostwo. Badacze podzielili zbiór placówek wg krajów rozwiniętych i rozwijających się. W 21\% przypadków dla krajów rozwijających się i 45\% w krajach rozwiniętych pobierano takie opłaty. Fab Laby w krajach rozwijających się finansowane są w fazie uruchomienia i bieżącej pracy w $74 \%$ z dotacji i grantów, podczas gdy w krajach rozwiniętych jest tak w $65 \%$ przypadków. Pod względem zaangażowania w projekty zewnętrzne - zlecone - Fab Laby w krajach rozwijających się były w nie bardziej zaangażowane niż w krajach rozwiniętych około 53\%, podczas gdy w krajach rozwiniętych w $28 \%$. Pod względem opłat za warsztaty 16\% respondentów z krajów rozwijających się częściowo za nie płaci, w krajach rozwiniętych jest tak w 19\% przypadków. Ponadto 16\% Fab Labów z krajów rozwijających się pobiera opłaty za wynajem maszyn i urządzeń, natomiast w krajach rozwiniętych - 25\%. Źródłem finansowania działalności bieżącej Fab Labów może być też sprzedaż wytwarzanych w nich innowacyjnych produktów i projektów - zarówno w krajach rozwijających się, jak i rozwiniętych nie stanowi ona dużego wsparcia finansowego, wynosi bowiem odpowiedni 5\% i 4\%. Darowizny jako źródło wsparcia finansowego to zaledwie 5\% w krajach rozwijających się i około $23 \%$ w państwach rozwiniętych. Można zatem stwierdzić, że Fab Laby znajdują się w połowie drogi pomiędzy działalnością nastawioną na zysk a organizacjami non profit, specyfika działalności i hybrydowe finansowanie wskazują, że sytuacja może być zmienna w czasie działania obiektu.

\section{Podsumowanie}

Na podstawie przedstawionych wyżej informacji o tym, czym są i jak działają Fab Laby (i podobne inicjatywy), warto w podsumowaniu artykułu zastanowić się, jakie korzyści i problemy idą w następstwie tych inicjatyw. Ogromną zaletą tych miejsc jest to, że podnoszą one poziom kultury technicznej. Jako projekt globalny docierają do krajów rozwijających się i sprawiają, że również i tam część mieszkańców ma możliwość kreatywnej pracy i edukacji. W Polsce także przyczyniają się do podniesienia kultury technicznej rozumianej jako istnienie $\mathrm{w}$ społeczeństwie kompetencji, myślenia i działania w sferze wytwarzania i rozwiązywania problemów technicznych, rozumienia działania techniki. W takim kraju jak Polska, który stoi przed widmem pułapki średniego rozwoju, gdzie własna myśl techniczna i liczba zgłaszanych patentów jest stosunkowo niewielka, wspieranie takich inicjatyw powinno stać się jednym z priorytetowych działań edukacyjnych i programowych. Kolejnym skutkiem działalności tych miejsc kreatywnych jest rozszerzenie działalności edukacyjnej poza ramy szkolnictwa, dają one bowiem szansę zdolnej młodzieży do rozwoju umiejętności wiedzy i kompetencji. Ważną zaletą Fab Labów i podobnych miejsc jest to, że mają one moc integrowania środowisk osób twórczych w danej miejscowości, ponadto usieciowienie krajowe i globalne daje możliwości działania na większą skalę i wymiany doświadczeń. Wśród zalet Fab Labów znajduje się ich działanie podnoszące poziom przedsiębiorczości i kreatywności w społecznościach lokalnych. Fab Laby dają możliwość uaktywnienia indywidualnych predyspozycji twórczych, pozwalają też na wytwarzanie nietypowych części i urządzeń (np. znane są przykłady stworzenia protez kończyn, części zamiennych do odrestaurowywanych pojazdów). Bardzo ważną 
i chyba nie do końca uświadomioną zaletą Fab Labów jest ich znaczenia dla niezamożnych mieszkańców miast pozbawionych przestrzeni i narzędzi do realizacji swoich pasji, np. modelarstwa. Fab Laby podnoszą więc jakość życia i tworzą lokalne wspólnoty, co ma ogromne znaczenie dla ruchów miejskich i społeczników. Działaniem i funkcjonowaniem Fab Labów mogą być też zainteresowani producenci urządzeń w nich pracujących, dają im one bowiem możliwość promowania i testowania sprzętu.

Do obiektywnej oceny działania Fab Labów brakuje niestety badań ewaluacyjnych przeprowadzonych na szerszą skalę. Warto byłoby zadać sobie pytanie: Jakie są wymierne korzyści z istnienia tego typu obiektów? I odpowiedzieć na nie konkretnymi danymi. To pytanie jest zasadne ze względu na zauważalną ekscytującą narrację, a nawet ideologię, która pojawia się $\mathrm{w}$ doniesieniach medialnych i piśmiennictwie o Fab Labach. Jak wskazano w artykule, rozwój tych inicjatyw zapoczątkowany w 2001 r. przyspieszył około roku 2009, liczba obiektów rośnie i stanowi dużą pulę do badań. W tym miejscu pojawia się pytanie o to, czy Fab Laby są czymś nowym na świecie. Odpowiedź brzmi „nie”, ale w spotykanej obecnie formie i zakresie działalności - „tak”. Ruch wytwórczości indywidualnej działał znacznie wcześniej, popularne hasło DIY (do-it-yourself) pojawiło się w 1912 r. (Gelber, 1997). Początkowo hasło to odnosiło się do drobnych prac rzemieślniczych i budowlano remontowych, ale stopniowo zaczęło rozszerzać swoje znaczenie. W Ameryce Północnej w pierwszym półwieczu XX w. istniało czasopismo poświęcone majsterkowiczom. Magazyny takie jak „Popular Mechanics” (założony w 1902 r.) i „Mechanics Illustrated” (założony w 1928 r.) umożliwiły czytelnikom naukę i zdobywanie wiedzy praktycznej dotyczącej technik, narzędzi i materiałów. Ruchy takie istniały w wielu państwach, również w Polsce, gdzie w telewizji emitowane były audycje, np. Adama Słodowego, wydawane było czasopismo „Młody Technik”. Współcześnie równolegle z Fab Labami spotykane są inne formy oddolnej i zdemokratyzowanej wytwórczości i kreatywności. Istnieją obiekty o nazwach z języka angielskiego: Hackerspaces, TechShop, Makerspaces - warsztaty i przestrzenie współpracy. Makerspaces i Hackerspaces są to otwarte miejsca spotkań, w których społeczność entuzjastów technologii może realizować projekty twórcze, uczyć się i dyskutować. Makerspaces to przestrzenie dla majsterkowiczów, służące wymianie wiedzy i umiejętności oraz tworzeniu własnych projektów. Hackerspace (hacklab - inna nazwa) mają podobne założenia, lecz są wyspecjalizowane w działalności informatycznej i hakerskiej, twórczości elektronicznej, programowaniu. TechShopy w odróżnieniu od Fab Labów to przestrzenie prywatne (prowadzone przez firmy i dla firm), do których dostęp nie jest otwarty dla wszystkich, ale przyznawany przez członkostwo. Ich wyposażenie jest też bardziej wyrafinowane. TechShop nie ma strony internetowej jak dzieje się to w Fab Labach. Przykładem może być Menlo Park TechShop w Stanach Zjednoczonych, we Francji Leroy Merlin TechShop otwarty w 2015 r. Do listy wymienionych miejsc oddolnej, społecznej kreatywności można dodać jeszcze Media Laby, miejsca, w których spotykają się twórcy, artyści, naukowcy, w odróżnieniu od Fab Labów zorientowane na kulturę i sztukę, produkcję medialną.

Przedstawione wyżej informacje o Fab Labach i podobnych inicjatywach oddolnych lub inspirowanych przez społeczności i twórców ukazują przez ich rosnącą liczbę nowy rodzaj miejsc w przestrzeni miast. Nie ustaliła się jeszcze w literaturze i wśród naukowców jedna wspólna nazwa dla tego typu przedsięwzięć. To, co je łączy, to umożliwienie kreatywnego działania, otwarcie na lokalną społeczność i większe lub mniejsze oparcie się na technologii. Propozycji może być tutaj wiele, np. „lokalne centra kreatywności”, „wspólnoty kreatywne”, „miejsca twórcze”. Fab Laby i podobne inicjatywy wymagają 
jeszcze szeregu badań, dziś i w perspektywie przyszłości dają nadzieję na poprawę poziomu kompetencji technicznych i społecznych.

\section{Literatura}

References

Bungart, S., (2014). Industrial Internet versus Industrie 4.0. Produktion - Technik und Wirtschaft für die deutsche Industrie. Pozyskano z: http://www.produktion.de/automatisierung/industrial-internet-versus-industrie-4-0/print

Gelber, S.M. (1997). Do-It-Yourself: Constructing, Repairing and Maintaining Domestic Masculinity. American Quarterly, 49(1), 66-112.

Gershenfeld, N.A. (2005). Fab Lab: The Coming Revolution on Your Desktop-from Personal Computers to Personal Fabrication. New York: Basic Books.

Hausner, J., Laurisz, N. (2008). Przedsiębiorstwa społeczne w Polsce. Teoria i praktyka. W: J. Hausner (red.), Czynniki krytyczne tworzenia przedsiębiorstw społecznych. Przedsiębiorstwo społeczne. Konceptualizacja. Kraków: Uniwersytet Ekonomiczny w Krakowie, 13.

Kagermann, H., Wahlster, W., Helbig. J., (2013). Recommendations for implementing the strategic initiative Industrie 4.0: Final report of the Industrie 4.0 Working Group.

Kaźmierczak, T., Przybysz, I., Potkańska, D., Rymsza, M., Schimanek, T. (2011). Przedsiębiorstwa społeczne: Czynniki trwałości, Raport z I fazy monitoringu przedsiębiorstw społecznych. Pozyskano z: https://inspro.org.pl/.../cwps/.../Przedsiebiorstwa_spoleczne_-_czynniki_trwalosci.pdf

Mikhak, B., Lyon, C., Gorton, T., Gershenfeld, N., Mcennis, C., Taylor, J. (2002). Fab Lab: an alternate model of ICT for development. Development by Design, (02), 1-7.

Osunyomi, D., Redlich, T., Buxbaum-Conradi, S., Moritz, M., Wulfsberg, J.P. (2016). Impact of the FabLab Ecosystem in the Sustainable Value Creation Process. OIDA International Journal of Sustainable Development, Ontario International Development Agency, Canada.

Osunyomi, D., (2015). Value Creation: FabLab's Journey so far. Helmut Schmidt Universitat. Pozyskano z: https://www.greenlab-microfactory.org/publications/

Tokushima, Y. (2016). Creating an Innovative Environment with FabLab - Case study: Bohol, the Philippines. New Breeze Winter, 28(1), 18-20.

Ustawa o przedsiębiorstwie społecznym (2015; 15 września 2018). Pozyskano z: http://www.ekonomiaspoleczna.gov.pl/Projekty,ustawy,o,przedsiebiorstwie,spolecznym,3861.html

Jacek Rudewicz, dr inż., Uniwersytet Szczeciński, Wydział Nauk o Ziemi. Jest adiunktem w Zakładzie Badań Miast i Regionów. Ukończył kierunek geografia ze specjalnością geografia społeczno-ekonomiczna, kierunek zarządzanie i marketing oraz ekonomia. W pracy naukowej zajmuje się studiami miejskimi, rozwojem zrównoważonym, rozwojem regionalnym oraz teorią systemów.

Jacek Rudewicz, PhD, Eng., University of Szczecin, Faculty of Geosciences. He has graduated from Geography with a specialisation in socioeconomic geography, also holds a degree in management and marketing and economics. He is an assistant professor in the Regional and Urban Studies Unit. His research interests focus on urban studies, sustainable development, regional development, systems theory.

ORCID: 0000-0002-2659-4754

\section{Adres/Address:}

Uniwersytet Szczeciński

Wydział Nauk o Ziemi

Zakład Badań Miast i Regionów

ul. Adama Mickiewicza 18

70-383 Szczecin, Polska

e-mail: jacek.rudewicz@univ.szczecin.pl 